\title{
PEMANFAATAN BUAH PEDADA (Sonneratia caseolaris) SEBAGAI BAHAN BAKU PEMBUATAN TEMPE DAN ANALISIS PROKSIMAT SERTA SIFAT ORGANOLEPTIKNYA
}

\author{
Yuni Fatisa, Dewi Pitasari
}

\author{
Program Studi Pendidikan Kimia, Fakultas Tarbiyah dan Keguruan, \\ Universitas islam Negeri Sultan Syarif Kasim Riau \\ Email: yunifatisa@yahoo.co.id
}

\section{ABSTRACT}

Pedada fruit (Sonneratia caseoiaris) potential as a food source because it contains high nutrient. In this study pedada fruit used as raw material for making tempe. Tempe is made by the fermentation time of 48 hours with 5 grams of tempe yeast and nutritional levels tested. The results showed the moisture content, ash content, fat content, protein content, and carbohydrate content are respectively 79,87\% (8Nl max 65\%); 1,76\% (8Nl max 1,5\%); 3,50\% (8NI $\min 10 \%) ; 3,90 \%$ (8NI $\min 10 \%$ ) and 10,96\% (8Nl max 2,5\%). Organoleptic test results it can be concluded that the panelists liked the tempe of pedada fruit with test scores for flavor, color, texture and scent are respectively 3,6; 3,4; 3,68; and 4,6. Flavor, color, texture and aroma the tempe of pedada fruit acceptable by the panelists.

Keywords: Pedada Fruit (Sonneratia caseoiaris), Tempe, Proximate Analysis, Organoleptic

\section{PENDAHULUAN}

Perubahan iklim (global climate changes), pertumbuhan penduduk serta keterbatasan lahan dan air telah mengakibatkan keterbatasan sumber daya pangan dan naiknya harga pangan di dunia. Akibatnya, kelaparan dan kekurangan gizi terjadi di berbagai negara. Hal ini bisa disebut dengan fenomena gizi buruk. Fenomena gizi buruk di Indonesia nampaknya hingga kini belum dapat teratasi secara maksimal. Terbukti dengan masih banyak ditemukannya daerah di Indonesia dengan status gizi yang rendah. Angka kematian akibat kasus gizi buruk pun dibeberapa daerah terus meningkat. Menurut Direktorat Bina Gizi dan Kesehatan Ibu dan Anak, setiap tahunnya tidak kurang dari satu juta anak di Indonesia mengalami status gizi yang buruk. Bahkan $45 \%$ dari kematian bayi dan balita diakibatkan oleh gizi buruk. Di dunia, Indonesia menempati urutan kelima yang memiliki kasus gizi buruk terbesar (Anonim, 2013).

Gizi buruk merupakan keadaan kurang gizi pada tingkatan yang sudah berat, yang disebabkan oleh kurangnya jumlah dan kualitas makanan yang dikonsumsi, seperti rendahnya konsumsi energi dan protein dalam makanan sehari-hari. Sedangkan faktor-faktor lain selain faktor kesehatan, yang merupakan masalah utama gizi buruk adalah faktor kemiskinan

Dengan keadaan seperti itu, Indonesia membutuhkan bahan makanan yang memiliki sumber gizi tinggi dan harga per satuan unit lebih murah. Tempe merupakan salah satu bahan makanan yang berprotein tinggi dan terjangkau apabila dibandingkan dengan sumber protein asal hewani, seperti daging, susu, dan telur

Tempe adalah makanan yang dibuat dari fermentasi terhadap biji kedelai atau beberapa bahan lain yang menggunakan beberapa jenis kapang Rhizopus oligosporus, Rh. oryzae, Rh. stolonifer (kapang roti), atau Rh. arrhizus (Hayati, 2009). Tempe saat ini menjadi barang mewah. Kedelai yang merupakan bahan baku tempe saat ini harganya melambung tinggi, sehingga tempe mahal seperti barang impor. Saat ini Indonesia masih tergantung impor kedelai dari beberapa negara. Impor dilakukan karena lahan untuk produksi kedelai terbatas sehingga stok tidak bisa memenuhi permintaan yang ada. Namun sekarang telah banyak masyarakat menggunakan bahan selain kedelai sebagai pembuatan tempe. Ada yang memanfaatkan kacang hijau, kacang kecipir, bahkan ada yang memanfaatkan ampas tahu dan 
ampas kelapa sebagai bahan baku pembuatan tempe (Suprapti, 2003).

Indonesia merupakan negara kepulauan terbesar di dunia dan memiliki potensi sumber daya pesisir dan lautan yang sangat besar. Salah satu sumber daya alam yang terdapat di daerah pesisir adalah hutan mangrove. Ekosistem mangrove memiliki manfaat ekonomis yaitu salah satunya adalah kayu sebagai bahan bakar. Salah satu jenis tumbuhan yang tumbuh di perairan mangrove adalah Pedada (Sonneratia caseolaris). Buah pedada memiliki beberapa kandungan triterpenoid dan sterol. Batang pedada memiliki kandungan kimia yaitu triterpenoid dan sterol (Manalu, 2011). Buah pedada memiliki kandungan protein, lemak, karbohidrat, vitamin, dan lainnya. Beberapa masyarakat telah memanfaatkan buah pedada untuk diolah sebagai sirup dan dodol, serta ada juga digunakan dalam pembuatan permen (Nurwati, 2011). Namun, di daerah Indragiri Hilir buah pedada masih belum dimanfaatkan secara optimal oleh masyarakat. Biasanya buah ini akan berjatuhan ketika matang, dan berserakan dan belum termanfaatkan dengan baik. Dalam Surah Al-A'raaf Ayat 130, Allah SWT menjelaskan tidak ada yang tidak bermanfaat yang Allah SWT ciptakan di bumi ini. Seperti hal nya buah pedada yang dapat dimanfaatkan menjadi lebih baik lagi.

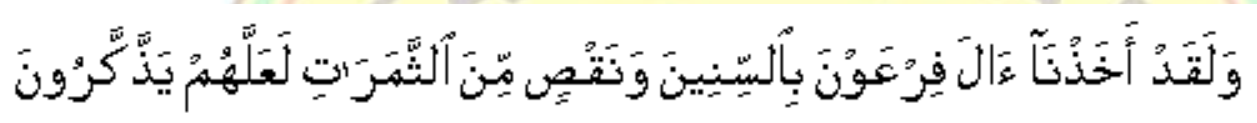

Artinya: "Dan sesungguhnya Kami telah menimpakan Firaun dan kaumnya dengan musim kemarau dan kekurangan buah-buahan, supaya mereka insaf mengambil pelajaran”. (QS Al A'raaf: 130).

Zat makanan (karbohidrat, protein, lemak, air dan abu) dari bahan makanan sangat penting untuk diketahui. Karbohidrat merupakan sumber kalori utama. Begitu juga dengan protein yang merupakan suatu zat makanan yang sangat penting yang berfungsi sebagai zat pembangun dan pengatur. Lemak juga merupakan zat makanan untuk menjaga kesehatan tubuh manusia. Kadar abu ada hubungannya dengan mineral suatu bahan. Kandungan air sangat berpengaruh terhadap konsistensi bahan pangan, erat hubungannya dengan keawetan bahan makanan (Manalu, 2011).

Beberapa produk olahan perlu dilakukan uji organoleptik terhadap rasa, warna, tekstur, dan aroma dari makanan yang dihasilkan. Karena kualitas terhadap makanan sangat penting untuk masyarakat. Uji organoleptik juga disebut pengukuran subjektif manusia sebagai alat ukur (Askar dan Sugiarto, 2005).

Untuk meningkatkan pemanfaatan buah pedada dan mendapatkan bahan pangan bergizi yang murah dan mudah didapat khususnya untuk masyarakat pesisir pantai maka peneliti tertarik untuk memanfaatkan buah pedada sebagai bahan baku pembuatan tempe dan mengetahui kadar nutrisi tempe menggunakan uji analisis proksimat serta sifat organoleptiknya.

\section{METODOLOGI PENELITIAN}

\section{Alat dan Bahan}

Alat yang digunakan antara lain kompor, pisau, alat kjeldahl lengkap dengan alat destruksi dan destilasi, desikator, neraca analitik, alat soxtec lengkap dengan aluminium cup, timbel, Aluminium voil, oven, cawan porselen, penjepit cawan, cawan crusible, tanur pengabuan, dan peralatan gelas laboratorium.

Bahan yang digunakan pada penelitian ini adalah buah pedada, ragi tempe, Metilen red, Brom kresol green, katalis $\left(1,5 \mathrm{~g} \mathrm{~K}_{2} \mathrm{SO}_{4}\right.$ dan 7,5 $\left.\mathrm{MgSO}_{4}\right), \mathrm{H}_{3} \mathrm{BO}_{3} 4 \%, \mathrm{NaOH} 40 \%, \mathrm{HCl} 0,1 \mathrm{~N}$, $\mathrm{H}_{2} \mathrm{SO}_{4(\mathrm{P})}$, petroleum benzen, dan aquades.

\section{Prosedur Kerja}

\section{Pembuatan Tempe dari Buah Pedada}

Buah pedada mengkal sebanyak 500 gr dikupas kulitnya kemudian dicuci bersih dan dipotong dadu. Potongan dadu buah pedada direbus selama 30 menit dan ditiriskan di nampan hingga kering. Setelah kering, ditambahkan 5 gram ragi, dan dibungkus 
menggunakan daun pisang. Kemudian difermentasi selama 48 jam.

Analisis Proksimat (Andarwulan, 2011)

\section{Penentuan Kadar Air (SNI 01-2891- 1992)}

Cawan kosong dan tutupnya dikeringkan dalam oven selama 15 menit dan didinginkan dalam desikator. Cawan kering ditimbang. Sebanyak 50 g sampel ditimbang dengan cepat kedalam cawan kering, kemudian dihomogenkan. Tutup cawan dibuka, cawan sampel beserta tutupnya dikeringkan dalam oven suhu $105^{\circ} \mathrm{C}$ selama 8 jam. Cawan yang berisi sampel dipindahkan kedalam desikator, ditutup dengan penutup cawan, didinginkan lalu ditimbang kembali. Cawan dimasukkan kembali ke dalam oven sampai memperoleh berat konstan.

$$
\% \text { Kadar } \text { Air }=\frac{\mathrm{a}-\mathrm{b}}{\mathrm{c}} \times 100
$$

Ket: $\mathrm{a}=$ berat cawan dan sampel basah

$\mathrm{b}=$ berat sampel awal/basah

$\mathrm{c}=$ berat cawan dan sampel kering yang sudah konstan

2. Penentuan Kadar Abu (AOAC, 2005)

Cawan crusible dipanaskan dalam oven pada suhu $105^{\circ} \mathrm{C}$ selama $1 \mathrm{jam}$, dan didinginkan dalam desikator lalu ditimbang $\left(\mathrm{w}_{1}\right)$. Ditimbang sebanyak 3 gr sampel $\left(\mathrm{w}_{2}\right)$ kemudian masukkan kedalam cawan crusibel tersebut dan dimasukkan kedalam tanur pengabuan, dibakar pada suhu $525^{\circ} \mathrm{C}$ selama 3 jam. Kemudian didinginkan dengan desikator selama 1 jam dan ditimbang $\left(\mathrm{w}_{3}\right)$.

$\%$ Kadar $A b u=\frac{(\mathrm{W} 2-\mathrm{W} 1) \mathrm{gr}}{\mathrm{W} 3(\mathrm{gr})} \times 100$

Ket: $\mathrm{w}_{1}=$ berat cawan kosong

$\mathrm{w}_{2}=$ berat sampel

$\mathrm{w}_{3}=$ berat cawan dan sampel setelah pengabuan

\section{Penentuan Kadar Lemak (AOAC, 2005)}

Aluminium cup dipanaskan dalam oven pada suhu $105^{\circ} \mathrm{C}$ selama 1 jam. Dinginkan dalam desikator kemudian Aluminium cup ditimbang $\left(w_{a}\right)$. Sampel ditimbang sebanyak $2 \mathrm{~g}$ $\left(w_{b}\right)$ dimasukkan ke dalam timbel kemudian tutup dengan kapas. Timbel yang berisi sampel dimasukkan pada soxtec, alat dihidupkan dan dipanaskan sampai suhu $135^{\circ} \mathrm{C}$ dan air dialirkan. Timbel diletakkan dalam posisi rinsing. Setelah suhu sampai $135^{\circ} \mathrm{C}$ (suhu telah normal), masukkan aluminium cup yang berisi $70 \mathrm{ml}$ petroleum benzen kedalam soxtec, lalu tekan start untuk memulai dengan posisi boiling, dilakukan selama 20 menit. Kemudian pada posisi rinsing dilakukan selama 40 menit, selanjutnya recovery 10 menit dengan posisi kran soxtec dibuka. Aluminium cup kemudian dimasukkan kedalam oven pada suhu $135^{\circ} \mathrm{C}$ selama 2 jam, kemudian dinginkan dalam desikator dan timbang $\left(w_{c}\right)$.

$\%$ Kadar Lemak $=\frac{W c-W a}{W b} \times 100$
Ket: $w_{a}=$ Berat awal aluminium cup
$w_{b}=$ Berat sampel
$w_{c}=$ Berat akhir setelah dioven

\section{Penentuan Kadar Protein (AOAC, 2005)}

Timbang 1 gr sampel masukkan kedalam digestion tubes straight yang ditambahkan katalis $\left(1,5\right.$ gr $\mathrm{K}_{2} \mathrm{SO}_{4}$ dan 7,5 mg $\left.\mathrm{MgSO}_{4}\right)$ dan ditambahkan $6 \mathrm{ml} \mathrm{H}_{2} \mathrm{SO}_{4(\mathrm{P})}$. Sampel didestruksi pada suhu $415^{\circ} \mathrm{C}$ selama 1 jam hingga cairan menjadi jernih (kehijauan). Kemudian sampel didinginkan dan ditambahkan aquades $30 \mathrm{ml}$ secara perlahan-lahan. Sampel dipindahkan kedalam destilasi dan disiapkan erlenmeyer 125 $\mathrm{ml}$ yang telah berisi $25 \mathrm{ml}$ larutan $\mathrm{H}_{3} \mathrm{BO}_{3}, 7 \mathrm{ml}$ metilen red dan $10 \mathrm{ml}$ brom kresol green. Ujung kondensor harus terendam dibawah larutan $\mathrm{H}_{3} \mathrm{BO}_{3} 4 \%$. Kemudian ditambahkan $30 \mathrm{ml}$ larutan $\mathrm{NaOH} 40 \%$ kedalam erlenmeyer dan didestilasi selam 3-5 menit. Tabung kondensor dibilas dengan air dan ditampung didalam erlenmeyer yang sama. Kemudian dilakukan titrasi dengan $\mathrm{HCl} \quad 0,1 \mathrm{~N}$ hingga terjadi perubahan warna pink. 


$$
\% \mathrm{~N}=\frac{(\mathrm{ml} \text { titran-ml blanko }) \times \text { Normalitas } x 14,007 \times 100}{\text { berat sampel }(\mathrm{mg})}
$$

\section{$\%$ Protein $=\% \mathrm{~N} \times$ faktor konversi}

Ket:

$4.25=$ Faktor konversi biji-bijian dari nitrogen ke protein

$14,007=$ Ar nitrogen

$\mathrm{N} \quad=$ Normalitas

\section{Penentuan Kadar Karbohidrat (SNI 01-2891-1992)}

Karbohidrat dapat dihitung dengan selisih antara 100\% dengan jumlah persentase berikut:

$$
\% \text { Kadar Karbohidrat }=100 \%-\% \text { (protein }+ \text { lemak }+ \text { air }+ \text { abu }
$$

\section{Pengujian Organoleptik}

Uji ini meliputi warna, rasa, aroma, dan tekstur yang ditentukan dengan uji kesukaan dari 25 panelis. Para panelis dikumpulkan dan diberi arahan atau penjelasan singkat tentang maksud dan tujuan dilakukan uji organoleptik. Kemudian sampel diberikan dan panelis mulai menguji sesuai kriteria yang telah ditentukan, sebelum mencicipi diharuskan minum air putih terlebih dahulu. Untuk uji rasa tempe buah pedada digoreng tanpa menggunakan bumbu, sedangkan warna, tekstur dan bau menggunakan tempe yang masih mentah. Panelis diharapkan memberikan penilaian berdasarkan tingkat kesukaan pada lembar angket. Uji ini ditentukan dengan menggunakan skala hedonik sebagai berikut:

Tabel 1. Skor Hedonik

\begin{tabular}{|l|l|}
\hline Tingkat Kesukaan & Skor \\
\hline Sangat suka & 5 \\
\hline Suka & 4 \\
\hline Kurang suka & 3 \\
\hline Tidak suka & 2 \\
\hline Sangat tidak suka & 1 \\
\hline
\end{tabular}

\section{HASIL DAN PEMBAHASAN \\ Pembuatan Tempe}

Dari penelitian yang telah dilakukan, diketahui bahwa buah pedada dapat diperlakukan sebagai bahan baku untuk pembuatan tempe. Hal ini dikarenakan setelah dilakukan perebusan dan fermentasi selama 48 jam, terbentuk hifa atau miselium pada permukaannya. Tempe pedada ini juga memiliki karakteristik aroma seperti jamur tempe serta tempe memiliki tekstur yang kompak. Ketika digoreng tempe buah pedada barbau layaknya tempe dari kedelai. Menurut Cahyadi (2009), tempe yang baik dan bermutu tinggi seharusnya memiliki flavor, aroma, serta tekstur yang khusus dan sangat karakteristik, harus padat dengan jahitan miselia yang rapat dan kompak, berbau seperti jamur (mushroom) yang segar dan berasa seperti daging ayam yang kompak. Sehingga bila diiris tempe tersebut tidak hancur.

\section{Analisis Proksimat}

Hasil analisis proksimat tempe buah pedada dengan pengulangan tiga kali dapat dilihat pada Tabel 2 berikut:

Tabel 2.

Hasil Analisis Proksimat Tempe Buah Pedada

\begin{tabular}{|c|c|c|c|c|c|}
\hline Kode Sampel & $\begin{array}{c}\text { Kadar Air } \\
(\boldsymbol{\%})\end{array}$ & $\begin{array}{c}\text { Lemak Kasar } \\
(\boldsymbol{\%})\end{array}$ & $\begin{array}{c}\text { Protein } \\
\text { Kasar }(\boldsymbol{\%})\end{array}$ & $\begin{array}{c}\text { Abu } \\
(\boldsymbol{\%})\end{array}$ & $\begin{array}{c}\text { Karbohidrat } \\
(\boldsymbol{\%})\end{array}$ \\
\hline $\mathbf{A 1}$ & 81,26 & 4,00 & 3,85 & 1,97 & 8,92 \\
\hline $\mathbf{A 2}$ & 78,49 & 3,50 & 4,02 & 1,66 & 12,50 \\
\hline A3 & 79,86 & 3,00 & 3,85 & 1,67 & 10,96 \\
\hline Jumlah & 239,61 & 10,50 & 11,72 & 5,30 & 32,38 \\
\hline
\end{tabular}




\begin{tabular}{|r|c|c|c|c|c|}
\hline Kode Sampel & $\begin{array}{c}\text { Kadar Air } \\
(\boldsymbol{\%})\end{array}$ & $\begin{array}{c}\text { Lemak Kasar } \\
(\boldsymbol{\%})\end{array}$ & $\begin{array}{c}\text { Protein } \\
\text { Kasar }(\boldsymbol{\%})\end{array}$ & $\begin{array}{c}\text { Abu } \\
(\boldsymbol{\%})\end{array}$ & $\begin{array}{c}\text { Karbohidrat } \\
(\boldsymbol{\%})\end{array}$ \\
\hline Rata-rata & 79,87 & 3,50 & 3,90 & 1,76 & 10,79 \\
\hline
\end{tabular}

a. Kadar Air

Analisis kadar air dilakukan dengan metode langsung yaitu dengan cara mengeluarkan air dari bahan pangan dengan bantuan pengeringan oven. Jumlah air dapat diketahui dengan cara penimbangan. Metode ini memiliki ketelitian yang sangat tinggi, tetapi memerlukan perlakuan yang relatif lama.

Kadar air yang didapat pada tempe buah pedada dengan fermentasi selama 48 jam adalah $79,87 \%$, sedangkan kadar air untuk tempe secara SNI maksimal 65\%. Tempe buah pedada memiliki kadar air yang cukup tinggi dibandingkan yang telah ditetapkan oleh SNI. Hal ini disebabkan oleh beberapa faktor yaitu, bahan baku dari tempe buah pedada memiliki kadar air yang cukup tinggi yaitu $79,24 \%$ pada buah pedada (Nurwati,2011). Pada penelitian lain terhadap tempe kedelai, selama proses fermentasi akan terjadi perubahan pada kadar air dimana setelah 24 jam fermentasi, kadar air kedelai akan mengalami penurunan sekitar $61 \%$ dan setelah 40 jam fermentasi akan meningkat lagi menjadi 64\% (Hayati, 2009).

Kadar air bahan baku tempe pada saat sebelum fermentasi juga mempengaruhi pertumbuhan kapang. Peningkatan kadar air disebabkan juga oleh penambahan air dari hasil metabolisme mikroba selama fermentasi. Selama fermentasi tempe, air dihasilkan sebagai hasil dari pemecahan karbohidrat oleh mikroba. Air merupakan hasil dari fermentasi aerob. Selama fermentasi tempe, mikroba mencerna substrat dan menghasilkan air, karbondioksida, dan sejumlah besar energi (ATP) (Dwinaningsih, 2010).

\section{b. Kadar Abu}

Analisis kadar abu dengan metode pengabuan kering dilakukan dengan cara mendestruksi komponen organik sampel dengan suhu tinggi didalam suatu tanur pengabuan, tanpa terjadi nyala api, sampai terbentuk abu berwarna putih keabuan dan berat konstan tercapai. Suhu yang digunakan adalah $525^{\circ} \mathrm{C}$ untuk buah-buahan dan hasil olahannya, daging dan hasil olahannya, gula dan sayur serta hasil olahannya. Pengaturan temperatur pengabuan harus diperhatikan karena banyak elemen abu yang dapat menguap pada suhu tinggi, misalnya unsur K, Na, S, Ca, Cl, dan P. Suhu pengabuan juga dapat menyebabkan dekomposisi senyawa tertentu. Sebelum diabukan sampel basah dikeringkan terlebih dahulu dalam oven pengering. Perlakuan ini dilakukan agar pada saat pengabuan tidak mengeluarkan asap. Setelah itu lalu masukkan kedalam tanur pengabuan dengan suhu dan waktu yang telah ditentukan (Andarwulan, 2011).

Pada tempe buah pedada kadar abu yang dihasilkan adalah $1,67 \%$. sedangkan yang ditetapkan oleh SNI kadar abu tempe maksimal $1,5 \%$. Penentuan kadar abu berhubungan erat dengan kandungan mineral yang terdapat dalam suatu bahan, kemurnian serta kebersihan suatu bahan yang dihasilkan. Mineral yang terdapat dalam bahan pangan terdiri dari 2 jenis garam, yaitu garam organik misalnya asetat, pektat, mallat, dan garam anorganik, misalnya karbonat, fosfat, sulfat, dan nitrat. Proses untuk menentukan jumlah mineral sisa pembakaran disebut pengabuan. Kandungan dan komposisi abu atau mineral pada bahan tergantung dari jenis bahan dan cara pengabuannya (Tandra, 2011).

Informasi mineral yang terkandung dalam tubuh manusia sekitar $4 \%$ dari berat badan. Dalam analisa makanan, mineral akan tertinggal sebagai kadar abu jika sampel makanan tersebut dibakar sempurna. Kadar abu ini menggambarkan banyaknya mineral yang tidak terbakar menjadi zat yang dapat menguap. Mineral terbagi menjadi dua golongan, yaitu mineral makro dan mineral mikro. Mineral makro adalah mineral yang dibutuhkan oleh tubuh dalam jumlah lebih dari $100 \mathrm{mg}$ per hari. Mineral mikro adalah mineral yang dibutuhkan tubuh dalam jumlah kurang dari $100 \mathrm{mg}$ per hari. Unsur yang termasuk mineral makro antara 
lain kalsium, fosfor, magnesium, natrium, klor, kalium, dan sulfur. Untuk mineral mikro adalah zat besi, seng, tembaga, iodium, mangan, molibden, dan kobalt.

\section{c. Kadar Lemak}

Metode ekstraksi yang digunakan adalah dengan analisis kadar lemak secara langsung, dengan cara mengekstrak lemak dari bahan dengan pelarut organik yaitu petroleum benzen. Digunakan suhu $135^{\circ} \mathrm{C}$ untuk menguapkan pelarut. Setelah pelarut diuapkan, lemak dari bahan dapat ditimbang dan dihitung persentasenya.

Pada tempe buah pedada kadar lemak yang dihasilkan sebesar 3,50\%. Kadar lemak tempe yang ditetapkan oleh SNI minimal 10\%. Proses fermentasi dibantu oleh laru tempe atau kapang tempe. Kapang tempe mempunyai aktifitas lipolitik yang kuat dan menghidrolisis sepertiga lemak selama fermentasi. Kapang secara aktif menghidrolisis protein dan melakukan proses deaminasi asam-asam amino.

Lemak adalah satu zat gizi makro yang memiliki peran penting bagi tubuh untuk menyimpan kelebihan energi yang berasal dari makanan. karena itu, lemak memiliki berbagai fungsi yang sangat penting untuk mempertahankan tubuh tetap sehat. dan kebutuhan lemak harian untuk orang indonesia adalah sekitar $15 \%$ dari kebutuhan energi total. Fungsi dari lemak adalah sebagai sumber energi, alat angkut vitamin larut lemak, penghemat protein, sebagai pelumas, memelihara suhu tubuh, dan pelindung organ tubuh (Arief, 2011).

\section{d. Kadar Protein}

Penentuan kadar protein dalam bahan makanan umumnya dilakukan dengan cara empiris atau tidak langsung. Penetuan kadar protein dengan cara empiris adalah dengan cara menghitung jumlah nitrogen $(\mathrm{N})$ pada suatu bahan makanan. Cara penetuan ini disebut dengan cara Kjeldahl. Cara ini dibagi menjadi tiga tahapan, yaitu proses destruksi, proses destilasi, dan tahap titrasi.

Proses destruksi (pemanasan), tahap detruksi ini dilakukan selama 1 jam dengan suhu $415^{\circ} \mathrm{C}$ untuk melepaskan nitrogen dari sampel. Pada tahap ini sampel dipanaskan dalam asam sulfat pekat sehingga terjadi destruksi menjadi unsurunsurnya. Elemen karbon, hidrogen teroksidasi menjadi $\mathrm{CO}, \mathrm{CO}_{2}$, dan $\mathrm{H}_{2} \mathrm{O}$. sedangkan nitrogennya akan berubah menjadi $\left(\mathrm{NH}_{4}\right)_{2} \mathrm{SO}_{4}$. Proses ini sudah selesai apabila larutan menjadi jernih atau tidak berwarna (Andarwulan, 2011).

Setelah proses destruksi selesai, larutan yang mengandung ammonium sulfat diperlakukan dengan penambahan alkali $(\mathrm{NaOH})$ pekat, untuk menetralkan asam sulfat. Dengan adanya larutan $\mathrm{NaOH}$ pekat ini, maka ammonium sulfat akan dipecah menjadi gas amoniak. Dengan melalui proses destilasi, gas amoniak ini kemudian akan menguap dan ditangkap oleh asam borat $\left(\mathrm{H}_{3} \mathrm{BO}_{3}\right)$ membentuk $\mathrm{NH}_{4} \mathrm{H}_{2} \mathrm{BO}_{3}$. Warna yang dihasilkan dalam proses destilasi ini adalah hijau.

Dalam tahap titrasi, senyawa $\mathrm{NH}_{4} \mathrm{H}_{2} \mathrm{BO}_{3}$ dititrasi dengan menggunakan $\mathrm{HCl}$ sehingga asam borat terlepas kembali dan terbentuk ammonium klorida. Jumlah asam klorida yang digunakan untuk titrasi setara dengan jumlah gas $\mathrm{NH}_{3}$ yang dibebaskan dari proses destilasi. Proses ini berakhir jika warna sampel berubah dari hijau menjadi pink.

Protein yang dihasilkan tempe buah pedada adalah 3,90\%. Ragi memegang peranan penting dalam meningkatkan nilai gizi protein selama proses fermentasi, hal ini disebabkan selama proses fermentasi Rhizopus oligosporus pada ragi mensistesis enzim protease. Jika dibandingkan dengan kadar tempe sesuai dengan SNI, maka tempe dari buah pedada ini belum bisa dikatakan memenuhi standar SNI tahun 2009. Kandungan protein untuk standar SNI minimal $16 \%$, sedangkan tempe buah pedada $3,90 \%$.

Kebutuhan manusia akan protein dapat dihitung dengan mengetahui jumlah nitrogen yang hilang. Kebutuhan protein untuk tubuh manusia rata-rata sebesar 1 gr protein $/ \mathrm{kg}$ berat badan per hari.

\section{e. Kadar Karbohidrat}

Di dalam tabel komposisi bahan pangan, kandungan karbohidrat biasanya diberikan sebagai karbohidrat total by difference, artinya kandungan tersebut diperoleh dari hasil 
pengurangan angka 100 dengan persentasi komponen lain (air, abu, lemak, dan protein).

Kadar karbohidrat tempe buah pedada adalah $10,96 \%$ sedangkan untuk kadar karbohidrat tempe dengan SNI tahun 2009 adalah maksimal 2,5\%.

Karbohidrat atau hidrat arang adalah suatu zat gizi yang fungsi utamanya sebagai penghasil energi, dimana setiap gramnya menghasilkan 4 kalori. Walaupun lemak menghasilkan energi lebih besar, namun karbohidrat lebih banyak di konsumsi sehari-hari sebagai bahan makanan pokok, terutama pada negara sedang berkembang. Di negara sedang berkembang karbohidrat dikonsumsi sekitar 70-80\% dari total kalori, bahkan pada daerah-daerah miskin bisa mencapai $90 \%$. Sedangkan pada negara maju karbohidrat dikonsumsi hanya sekitar 40-60\%. Hal ini disebabkan sumber bahan makanan yang mengandung karbohidrat lebih murah harganya dibandingkan sumber bahan makanan kaya lemak maupun protein. Walaupun tubuh tidak membutuhkan dalam jumlah yang khusus, kekurangan karbohidrat yang sangat parah akan menimbulkan masalah. Diperlukan sekitar 2 gram karbohidrat per $\mathrm{Kg}$ berat badan sehari untuk mencegah terjadinya ketosis.

Secara umum, tempe mengandung berbagai senyawa aktif antara lain sejumlah lemak, berbagai mineral baik makro maupun mikro, protein nabati, serat pangan alami, karbohidrat, isoflavon, vitamin yang larut dalam air maupun yang larut dalam minyak. Begitu juga tempe dari buah pedada yang mengandung berbagai kandungan nutrisi. Berdasarkan kadar nutrisinya, tempe buah pedada dapat dijadikan sebagai sumber makanan alternatif bagi kebutuhan manusia di masa mendatang khususnya di daerah pesisir pantai dan dapat membantu menyelesaikan masalah pangan.

\section{Sifat Organoleptik}

Sifat organoleptik adalah sifat dari bahan pangan yang dinilai dengan menggunakan panca indra, merupakan penilai yang bersifat subyektif. Penilaian cara ini dapat dilaksanakan dengan cepat dan langsung.

\section{a. Rasa}

Rasa adalah rangsangan yang dihasilkan suatu produk setelah dimakan terutama dirasakan oleh indera pengecap sehingga dapat mengidentifikasinya. Dalam pengawasan mutu makanan, rasa termasuk komponen yang sangat penting untuk menetukan penerimaan konsumen. Meskipun demikian, rasa adalah suatu yang nilainya sangat relatif. Umumnya bahan pangan tidak hanya terdiri dari salah satu rasa, tetapi merupakan gabungan dari berbagai rasa secara terpadu sehingga menimbulkan cita rasa yang utuh. Rasa tempe buah pedada pada dasarnya gurih dan berbau layaknya tempe pada umumnya. Hasil rata-rata uji hedonik terhadap rasa tempe buah pedada adalah 3,48 (suka), hal ini menunjukkan bahwa panelis menyukai tempe dari buah pedada. Tempe buah pedada dapat diterima dari segi rasa oleh panelis.

\section{b. Warna}

Warna adalah kenampakan yang diamati dengan indera penglihatan. Penentuan mutu bahan makanan pada umumnya tergantung pada faktor mikrobiologis secara visual faktor-faktor penunjang yang lain. Selain itu faktor yang ikut menentukan mutu adalah warna. Warna dapat digunakan sebagai indikator kematangan. Warna tempe dari buah pedada adalah putih keabuabuan sedangkan tempe yang telah dilakukan perlakuan penggorengan yaitu berwarna kuning keemasan layaknya tempe yang goreng pada umunya. Hasil rata-rata uji hedonik terhadap warna tempe buah pedada adalah 4,12 (sangat suka), hal ini menunjukkan bahwa panelis menyukai warna dari tempe pedada yang layaknya seperti tempe pada umunya. Tempe buah pedada dapat diterima dari segi warna oleh panelis.

\section{c. Tekstur}

Tekstur adalah sifat kekompakan dari produk makanan yang diamati dengan indera peraba. Tekstur tempe dari buah pedada yang dihasilkan adalah kompak. Hasil rata-rata uji hedonik terhadap tekstur tempe pedada adalah 3,56 (suka), hal ini menunjukkan bahwa panelis menyukai tekstur dari tempe buah pedada yang kompak. Tempe buah pedada dapat diterima dari segi tekstur oleh panelis. 


\section{d. Aroma}

Aroma adalah rangsangan yang dihasilkan dan diketahui dengan indera pembau. Indera pembau adalah instrumen yang paling banyak berperan mengetahui aroma terhadap makanan. Dalam pengujian indrawi, bau lebih komplek dari pada rasa. Bau atau aroma akan mempercepat timbulnya rangsangan kelenjar air liur. Hasil rata-rata uji hedonik terhadap aroma tempe pedada adalah 4,72 (sangat suka), hal ini menunjukkan bahwa panelis menyukai aroma dari tempe buah pedada yang berbau jamur tempe atau ragi tempe.

Dari hasil penelitian yang didapat buah pedada yang kaya akan nutrisi, dapat dijadikan sebagai tempe. Tempe buah pedada dapat dijadikan makanan pengganti khususnya bagi masyarakat di daerah pesisir. Masyarakat pesisir dapat memanfaatkan tempe buah pedada sebagai sumber gizi dari nabati. Disamping harga kedelai yang meningkat dan ditambah dengan harga BBM yang meroket untuk tahun ini, maka tempe dari buah pedada dapat dijadikan sebagai alternatif tempe didaerah pesisisr pantai.

\section{KESIMPULAN DAN SARAN}

Berdasarkan penelitian yang dilakukan dapat diambil kesimpulan sebagai berikut:

Kadar nutrisi tempe buah pedada yaitu kadar air, abu, lemak, protein, dan karbohidrat masingmasing berturut-turut adalah $79,87 \% ; 1,76 \%$; $3,50 \%$; $3,90 \%$; dan $10,96 \%$. Uji organoleptik secara keseluruhan menyatakan bahwa panelis menyukai tempe berbahan dasar buah pedada.

Untuk penelitian selanjutnya, penulis menyarankan agar melakukan fortifikasi atau penggabungan bahan pangan lain dengan buah pedada untuk meningkatkan kadar nutrisi pada tempe buah pedada.

\section{DAFTAR PUSTAKA}

Almatsier, Sunita. 2002. Prinsip Dasar Ilmu Gizi. Jakarta: Gramedia Pustaka Utama.

Andarwulan Nuridkk.2011. Analisis Pangan. Jakarta: Dian Rakyat

Anonim. 2013, Gizi Buruk Mengancam Stabilitas Negara, http://kesehatan. kompasiana.com/makanan/2013/02/07/g izi-buruk-mengancam-stabilitas-negara531574.html, diakses tanggal: 16 Februari 2013.

2013. Uji Organoleptik. http://id.wikipedia.org/wiki/Uji_organol eptik, Tanggal Akses: 21 Maret 2013.

Arief, Ria Qadariah. 2012. Fungsi Lemak. http://www.konsultankolesterol. com/fungsi-lemak/, tanggal akses: 23 Juli 2013.

Askar, Surayah dan Sugiarto. 2005. Uji Kimiawi dan Organoleptik sebagai Uji Mutu Yoghurt. Bogor: Balai Penelitian Ternak.

Badan Standarisasi Nasional. 2009. Tempe Kedelai. Jakarta: BSN

Cahyadi, Wisnu. 2009. Kedelai Khasiat dan Tegnologi. Jakarta: PT. Bumi Aksara.

Dwinaningsih, Erna Ayu. 2010. Karakteristik Kimia dan Sensorik Tempe dengan Variasi bahan Baku Kedelai/Beras dan Penambahan Angkak serta Variasi Lama Fermentasi, skripsi. Surakarta: Universitas Sebelas Maret.

H, Satrohamidjojo. 2005. Kimia Organik Stereokimia, Karbohidrat, Lemak, dan Protein. Yogyakarta: Gadjah Mada University Press.

Hayati, Salma. 2009. Pengaruh Waktu Fermentasi Terhadap Kualitas Tempe dari Biji Nangka (Artocarpus Heterophyllus) dan Penentuan Kadar Zat Gizinya, skripsi. Medan: USU.

Himpunan Ahli Kesehatan Lingkungan Indonesia. 2012. Faktor Penyebab Gizi Buruk.

http://indonesianpublichealth.blogspot.c om/2012/10/faktor-penyebab-giziburuk.html, tanggal akses: 16 Februari 2013.

Manaru, Ruth Dwi Elsa. 2011. Kadar Beberapa Vitamin pada Buah Pedada (Sonneratia Caseolaris) dan Hasil Olahannya, skripsi. Bogor: ITB.

Muchtadi, Deddy. 2009. Prinsip Teknologi Pangan Sumber Protein. Bandung: Alfabeta. 
Noor, Yus Rusila. 2006. Panduan Pengenalan Mangrove di Indonesia. Bogor: Wetland International.

Novalina. 2009. Analisis Proksimat. $\mathrm{http}: / /$ novalinahasugian.blogspot.com /2009/06/ pendahuluan - analisisproksimat- adalah. html, tanggal akses: 25 Juli 2013.

Nurwati, 2011. Formulasi Hard Candy Dengan Menambahkan Ekstrak Buah Pedada (Sonneratia caseolaris) Sebagai Flavor, skripsi. Bogor: ITB.

Priyono, Aris, Dkk. 2010. Beragam Produk Olahan Berbahan Dasar Mangrove.Jawa Tengah: KeSEMAT.

Soedjono. 2006. Kacang-kacangan. Bandung: Rosda.
Soekarto, Soewarno T. 1985. Penilaian Organoleptik. Jakarta: Bhratara Karya Aksara.

Suprapti, Lies. 2003. Teknologi Pengolahan Pangan: Pembuatan Tempe. Yogyakarta: PT.Kanisius.

Tandra, Rian Reksi. 2011. Kadar Abu. http://rianrtandra.wordpress.com/tag/kad ar-abu/, tanggal akses: 23 Juli 2013.

Winarno, F, G. 2004. Kimia Pangan dan Gizi. Jakarta: PT Gramedia Pustaka Utama.

Winarno, F, G. Fardiaz, S. 1993. Biofermentasi dan Biosintesa Protein. Bandung: Angkasa.

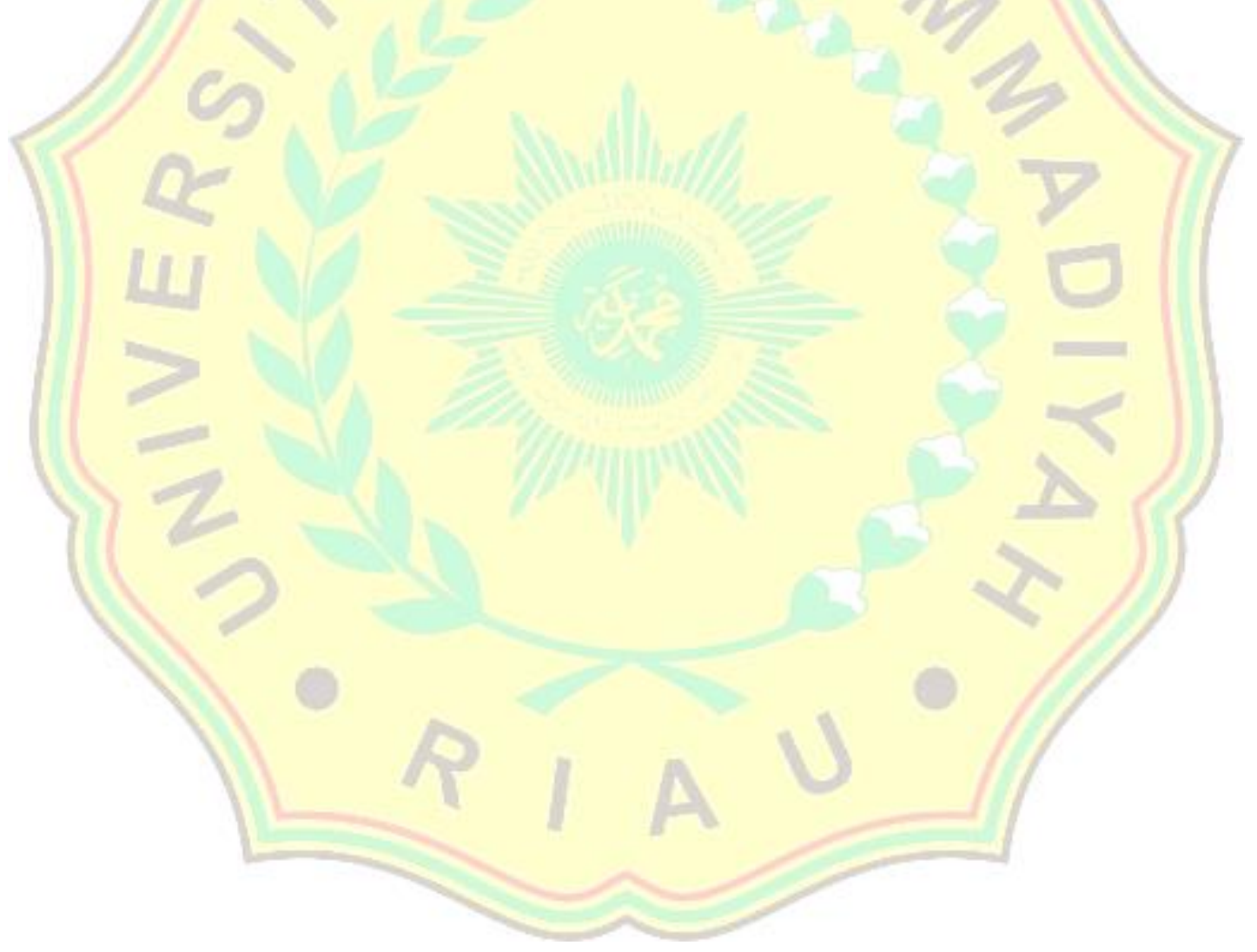

